\title{
Postdigital: A Term That Sucks but Is Useful
}

\author{
Florian Cramer $^{1} \cdot$ Petar Jandrić ${ }^{2,3}$
}

Accepted: 4 March 2021 / Published online: 31 March 2021

(c) The Author(s), under exclusive licence to Springer Nature Switzerland AG 2021

Keywords Postdigital · Arts · Artistic research · DIY · Self-organization · Design · Crapularity $\cdot$ Science $\cdot$ Education $\cdot$ Activism $\cdot$ Algorithm $\cdot$ Magic $\cdot$ Speculative fiction · Conspiracy

\section{Introduction}

Florian Cramer studied Comparative Literature and Art History at Freie Universität Berlin, Universität Konstanz, and University of Massachusetts at Amherst, and obtained his Dr. Phil. in Comparative Literature in 2006 with a thesis on the history on combinatorial and permutational poetry and literature (Cramer 2011). Between 1998 and 2004, he worked as a lecturer in Comparative Literature at Freie Universität Berlin's Peter-Szondi-Institut. Since 2004, he has been working at Willem de Kooning de Academy/Piet Zwart Institute in Rotterdam. In 2004, he was a research fellow, between 2006 and 2010 the course director of Master Media Design, and since 2008 he has been a reader/practice-oriented research professor for the whole school. Florian's current work is focused on self-organized, multidisciplinary, and do-it-yourself (DIY) practices in relation to new concepts and understandings of autonomy in the arts. He co-initiated multidisciplinary research projects in the Netherlands including ACKnowledge: Artists Community Knowledge, and Making Matters: Bridging Art, Design and Technology through Material Practices.

Since 1989, Florian has collaborated in DIY publishing and activist projects with Lloyd Dunn/PhotoStatic, Stewart Home, John Berndt, tENTATIVELY, a cONVENIENCE and Istvan Kantor (in- and outside of the context of Neoism), Karlheinz Essl, Heinrich Dubel, Sebastian Luetgert, Rafael Horzon, Luther Blissett/Wu Ming 1, Eva and Franco Mattes, Cornelia Sollfrank, Alan Sondheim, mez breeze (in the larger context of

Petar Jandrić

pjandric@tvz.hr

Florian Cramer

j.j.f.cramer@hr.nl

1 Willem de Kooning Academy/Piet Zwart Institute, Rotterdam University of Applied Sciences, Rotterdam, Netherlands

2 Zagreb University of Applied Sciences, Zagreb, Croatia

3 University of Wolverhampton, Wolverhampton, UK 
net.art and codeworks), Tatiana Bazzichelli, Katrien Jacobs (on alternative pornography and network culture), Coolhaven, Jeroen Kuster, Mariëtte Groot, filmwerkplaats collective, Lukas Simonis and Ergo Phizmiz, De Player (in Rotterdam's DIY arts and experimental music/filmmaking communities), Jan Van Den Dobbelsteen, Paolo Davanzo and Lisa Marr, Wilhelm Hein and Annette Frick, Rasheedah Phillips, Moor Mother (helping to organize the 2015 festival 'Afrofuturism Now'), Frank Rowenta, Goodiepal and Pals, Clara Balaguer and Woodstone Kugelblitz/The Voluntary Fire Brigade of the Apocalypse.

In 1998, Florian won an electronic literature award for the website Permutations ${ }^{1}$ which reconstructs historical, pre-electronic combinatorial poetry as computergenerated poetry. His publications include the essay collection Anti-Media (2013), a series of essays on postdigitality published between 2012 and 2016 (e.g. Cramer 2013a, b, 2015) and a series of essays on 'Crapularity' which has been published since 2016 (e.g. Cramer 2018a, b; 2019).

\section{About the Interview}

Florian Cramer and Petar Jandrić met as invited speakers at the ENCATC Digital Congress, 'Cultural management and policy in a post-digital world - navigating uncertainty', held online from 3 to 11 November $2020^{2}$, and agreed to an interview. This article was written during a series of e-mail exchanges between January and March 2021.

\section{Postdigital Magic}

Petar Jandrić (PJ): In Words Made Flesh: Code, Culture, Imagination, you wrote: 'Material creation from the word is an idea central to magic in all cultures; it is precisely what magic spells perform. Magic therefore is, at its core, a technology, serving the rational end of achieving an effect, and being judged by its efficacy.' (Cramer 2005: 14-15) Moving to the case of computer software, you continued: 'The technical principle of magic, controlling matter through manipulation of symbols, is the technical principle of computer software as well. It isn't surprising that magic lives on in software, at least nominally.' (Cramer 2005: 15) Sixteen years after you wrote these words, I would argue that the magical character of software is beyond nominal; a typical case in the point are recommender systems that know our desires better than we do. Yet our time is radically different from the time of ancient shamans and religions. What are the defining features of today's postdigital magic?

Florian Cramer (FC): I am not sure whether 'analog magic' is a thing of the past. Shamanism, for example, is still a global practice and embedded into everyday life in many parts of the world, (prominently) including the high-tech country South Korea. Much of my knowledge of ethnological study of magic, beyond the Western hermetic tradition, came from studying with Robert Stockhammer,

\footnotetext{
1 See http://permutations.pleintekst.nl/. Accessed 18 February 2021.

2 See https://encatccongress.org/programme/. Accessed 18 February 2020.
} 
the literary scholar and author of Zaubertexte: Die Wiederkehr der Magie und die Literatur 1880-1945 (2000). In Robert's 1990s seminar, I read-among others-the anthropologist Stanley Jeyaraja Tambiah. Michael Oppitz' (1981) documentary Shamans of the Blind Country and Lindsey Merrison's (2001) documentary Friends in High Places on Nat spiritualism in Myanmar were eye-openers on magic and spirituality as everyday technologies (see Fig. 1). More recently, I have also watched social media videos on magical practices in the Philippines shared by my friend and collaborator Clara Balaguer.

What I learned from Robert and took away from the other sources is that magic is, first of all, an everyday technology. In most places and situations, it is radically pragmatic and goal oriented. You perform an act of magic in order to achieve a specific objective, and the magic will ultimately be judged according to its efficacy. Conversely, software and algorithms are judged by their efficacy in many, if not most cases, without knowing how they internally work-a problem that becomes even more prominent with neural network/deep learning-based Artificial Intelligence (AI) where internal decision-making criteria of the software are, by default, opaque and very difficult to reconstruct.

Here, the term 'postdigital' strikes me as still being useful—because from a postdigital perspective, you would no longer consider 'analog' and digitalalgorithmic magic to be two different things. Instead, you would analyse them as one comprehensive phenomenon, perhaps using the methodologies and criteria of Tambiah rather than those of New Media Studies, or combining the two. In such an analysis, one may end up finding that the criterion of 'analog' versus 'digital' is not the most important-and that might it be more relevant to investigate others, such as the relation between metaphysics and ontology in these acts and technologies.

PJ: Magic and belief have always been political, and the power of secular democratically elected leaders is closely tied to religion. [A good recent case in the point is Donald Trump and his relationship with Evangelical Christian movements in the US (McLaren 2020)]. Instead of delving into daily politics, however, I would like to examine the political nature of algorithmic code at a deeper level, using your (now textbook) example of Richard Stallman and his Free Software movement:

The popular, anonymous hacker credo that 'information wants to be free' supposes a political semantics embedded into formal, digital code, by its technical virtue of boundless and lossless replication. ... The Free Software movement translates the logic of executable code into a number of other executable codes: the GNU manifesto as a political instruction code, the GNU licenses as a legal code, free software documentation as a technical instruction code. (Cramer 2015: 50)

Politics is not only a consequence of usage of software; it is also inscribed in the very structure of software code. Yet politics is inscribed into code by people who live and work in a certain political economy, thus closing a full dialectic between software creation and usage. What is your take on this dialectic? 
FC: The quote above is from a text I wrote in 2004 when I was a fellow at Piet Zwart Institute in Rotterdam as part of larger research project on software studies initiated by Matthew Fuller and Femke Snelting (Fuller 2008). This essay summed up my own experience as a Debian GNU/Linux user since 1997, as a member of the Berlin Linux User Group, ${ }^{3}$ a contributor to the organization of the Wizards of $\mathrm{OS}^{4}$ conferences in Berlin which were initiated by Volker Grassmuck, and which investigated the intersections of Free Software and culture from 1999 to 2006. During the 1999 conference (and a bit longer), Richard Stallman lived at my place.

A major inspiration for Wizards of OS and its attempt to investigate the bigger picture of Free Software, code, society, and culture in their interrelatedness was Lawrence Lessig's (1999/2006) book Code and Other Laws of Cyberspace. Lessig, a legal scholar who lived and lectured in Berlin as a research fellow in 1999, suggested that software - and algorithms - function like the law and had ascended, through the Internet and its corporations, to a new legal regime. I thought that Lessig's observation was important, but lacked elaboration. His analysis in the book, in my opinion, did not live up to the radicality of his basic observation.

Today, it seems as if the fields of media studies, and critical analysis of digital technology, software, and now also artificial intelligence, are still in the process of grasping and analysing the consequences of this observation. Cybernetics had, of course, reflected on the politics of control processes early on, among others with Norbert Wiener's The Human Use of Human Beings (1950). However, cybernetics did not yet think of software and algorithms as forces in their own right, but only as parts (and special cases) of larger feedback and control systems. This continued in media theory-including Friedrich Kittler's infamous (1992) claim that '[t]here is no software' - until the early 2000s. My quote must be seen as belonging to a particular discourse among a particular generation and network of people who coauthored the MIT Press' Software Studies: A Lexicon (Fuller 2008), to correct that oversight, and to think of software in broader cultural and political terms, i.e., of software having its own culture and politics.

PJ: The politics of today's artificial intelligences and other 'self-thinking' entities are getting progressively more and more distant from the politics of their creators. As we 'teach' our AIs using large datasets, their conclusions and practices are starting to live their own lives. What kind of political agency is emerging in our age of rapidly developing AIs?

FC: Having tried to describe a larger cultural-poetic and speculative-history of executive codes in this essay from 2004, I must, however, admit that I got somewhat fed up with the subject, and rather consider it something that haunts me. In my private life, too, I ended up tinkering and experimenting with computers less often-although I have been a staunch Unix/Linux command line computing person and Debian GNU/Linux user now for almost two and a half decades. Instead, I became more interested in photography and moving images.

\footnotetext{
3 See https://www.belug.de/home.html. Accessed 10 February 2021.

${ }^{4}$ See http://wizards-of-os.org/. Accessed 10 February 2021.
} 
Fig. 1 Screenshots from the documentary Friends in High Places (Merrison 2001), where an interviewee explains how offerings to the Nat spirits work in practice

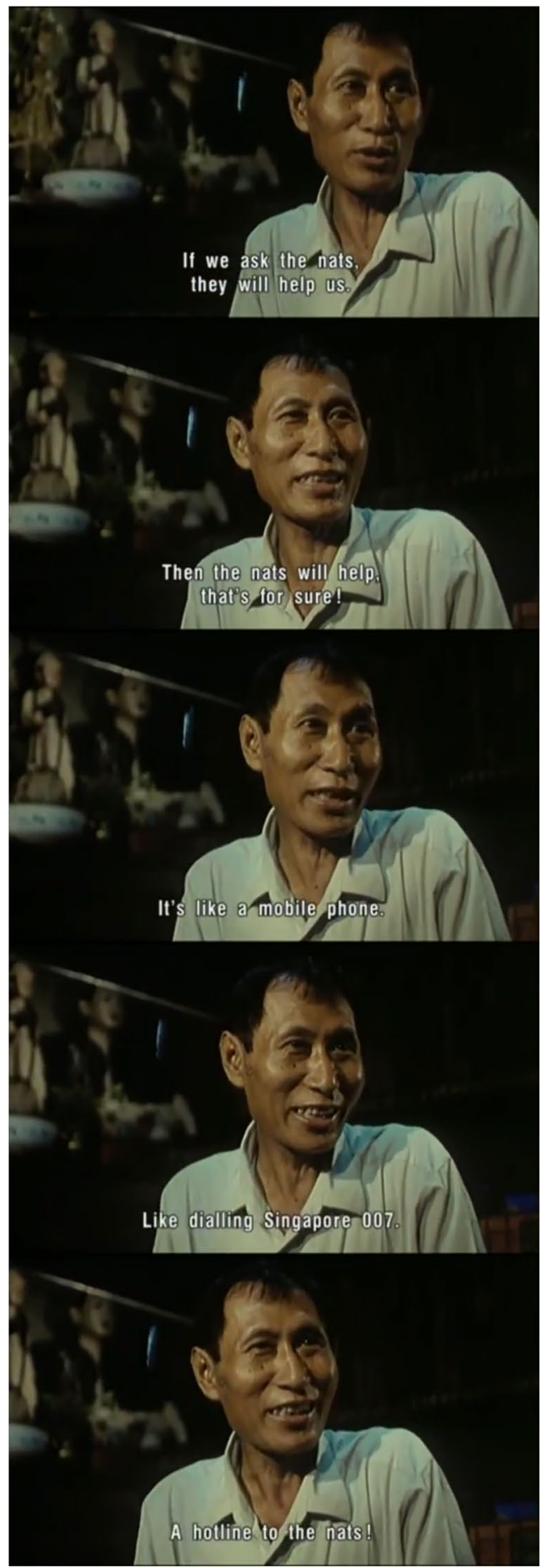


Just recently, I tried in a conference paper to revisit and more precisely pin down this ennui on what I propose to call 'the kaleidoscope constraint' (Cramer 2020). In my experience, any algorithmic or otherwise automated system that manipulates symbols, or any automated creativity boils down to a glorified kaleidoscope: interesting and maybe fascinating to observe in the beginning, yet repetitive and tedious in the long term, even when the output contains no literal repetitions. In my $\mathrm{PhD}$ dissertation, I worked around this issue by focusing on the speculative imagination surrounding these systems rather than on the systems themselves, with my teacher Renate Lachmann and her concept of fantastic literature (Lachmann 2002), and my PhD supervisor Gert Mattenklott, and his concept of aesthetic anthropology (Mattenklott 1989). These ideas were major inspirations.

Otherwise, the best uses of such systems have been, in my view, as tactical tools of social intervention, as in, for example, Cornelia Sollfrank's use of her 'net.art generators' as cultural, political and legal inquiries into intellectual property (Sollfrank 2004). Working with younger-generation DIY-cultural artists who did not really care about digital/analog divides, and collaborating with Alessandro Ludovico in my school's research program, eventually led me to think of postdigitality.

But maybe I can answer your question pragmatically, not as a scholar, but as someone who has become a political activist in the last four years with the Dutch intersectional political party $\mathrm{BIJ} 1^{5}$ and affiliated anti-fascist and anti-racist movements, and from my 2016 analysis of the American 'Alt-Right' movement. ${ }^{6}$ Today, political activism, to a major degree, boils down to feeding Internet platform filter algorithms, and trying to estimate and control the algorithmic-social dynamics of messages you place. In other words, political agency has become about meme-ing, 'going viral' and gaming algorithms for this purpose. This collaboration and cohabitation of human and algorithmic actors could probably simply be described and analysed with Latour's actor-network theory.

PJ: Speaking of agency, we immediately ended up in a deeper question of posthumanism. While some authors see today's relationships between humans and technologies in terms of radical equality, others are more careful and speak of a symmetry. For instance, Chris Jones claims that 'all actors cannot be treated as completely symmetrical for research purposes because of the particular access that we have to accounts of experience from human actors' (Jones 2018: 51). What is your take on this radical equality, and/or symmetry, in our postdigital reality?

FC: I probably understand 'postdigital' differently from how it is being used now-namely, and literally as a perspective that finds the distinction between 'digital' and 'non-digital' to be less clear than it seems when it is rigorously inspected, and also less useful and relevant than it often seems. The postdigital perspective thus breaks with the 'new media' paradigm, and would even argue that most of the 'principles' of new media as defined by Manovich (2002) are not specific to digital technology. Manovich (2002) defines 'new media' according to the 'five principles'

\footnotetext{
5 See https://bij1.org/. Accessed 10 February 2021.

6 The original 2-h video lecture, given at Willem de Kooning Academy Rotterdam, is no longer online; a shorter version is available at https://youtu.be/OiNYuhLKzi8. Accessed 23 February 2021.
} 
of 'numerical presentation', 'modularity', 'automation', 'variability', and 'transcoding'. These principles were commonly employed in experimental arts before the availability of computing, and continue to be employed in non-computational practices such as artists' books and artist-run handmade film labs.

Conversely, one could even argue that the hegemony of smartphones with their closed operating systems and app ecosystems have, since the 2010 s, greatly constrained, if not cancelled out, four of Manovich's five principles of new media: modularity (the possibility of combining digital information), variability (the possibility of making variations and versions), automation (the possibility of programming) and transcoding (the possibility of translating media into other formats). For users, a vintage analog 16- or 35-mm film editing table or a reel-to-reel tape recorder now meets those 'new media' criteria better than a social media app like TikTok.

Going back to our example of magic, I would argue that the same arguments on human versus technological actors can be made for traditional magic, so I do not think that current times introduce something fundamentally new in this respect. As to whether we should think of their relation in terms of equality or symmetry, I have to pass on this.

What I find questionable, however, in many posthumanist models is that they ascribe autonomy to machine processes often simply out of a lack of insight and understanding of the economic, political, engineering design, etc. powers and agendas that are shaping them. This was also the software studies' critique against earlier anti-, post- and transhumanist schools of media theory and 'cyber culture'. An old favourite quote of mine is by the artist Ulrike Gabriel who said, in a personal conversation in 2001, that there is no such thing as randomness in computing because the fact of the machine standing there is itself not a random occurrence. This can be broadened to machine autonomy, and machine agency, in general. You first need to ask who put it there, and with which agenda.

\section{Arts and Speculative Machines}

PJ: You have participated, in various forms and capacities, in many artistic movements and (sub)cultural networks since the 1990s, including in Neoism and net.art, which serve as important influences on today's movements such as Anonymous (Moioli 2016). Building on the previous question, what is the relationship between technology and contemporary artistic practice?

FC: I wasn't really involved in net.art but knew, and am friends and occasional collaborators with a number of net.artists. Neoism, in my opinion, is better characterized as underground DIY than art. Coming from this background, I was never actually interested in the relationship of technology and art per se-which would be the traditional domain of 'Art/Science' and media art. Instead, I am interested in cultural shifts, revisions or even revolutions that go hand-in-hand with new technologies and get accelerated through them. This is where I also found a common ground or mindset with first- and second-generation net.art practitioners such as Cornelia Sollfrank, heath bunting, mez breeze and Franco and Eva Mattes. 
For example, major shifts addressed by Neoism, as well as in Internet piracy and meme culture, are the collapse of traditional categories of authorship, (art)work and ownership. In Neoism, this took place through the use of shared identities such as Monty Cantsin, open advocacy of plagiarism and anti-copyright. The cultural shifts also refer to automation and viral multiplication versus traditional authorship and traditional mass media. The computer interested me in its potential as a speculative machine that simplified and escalated certain poetics, such as permutational poetry, aleatoric composition, cut-ups, bots, anti-copyright-but I have never been interested in arts that take the machine as their point of departure.

PJ: What you describe here also represents a blurred relationship between arts and activism. For instance, Neoist use of shared identities in the 1980s and 1990s was soon appropriated by the Anonymous movements. Open advocacy of plagiarism and anti-copyright today takes many shapes such as Marcell Mars and Tomislav Medak's Public Library project, ${ }^{7}$ which is equally at home in arts, activism and information science. What is your take on this dynamic between arts, activism and social change?

FC: If one takes the term 'contemporary art' literally, instead of understanding it like the philosopher Peter Osborne (2013) and others do, as a certain style and period of post-minimalist white cube art, then these multidisciplinary, blurry-boundary practices are now at the core of many, if not most, contemporary arts practices. I should add that these practices are not limited to blurring art and activism, or combining art with social change, but overlap with other, and potentially even any, field of practice and knowledge.

This is also happening in the established contemporary art system, if you look, for example, at the upcoming documenta $2022^{8}$ which will be curated by the Indonesian ruangrupa collective. ${ }^{9}$ My own work, and that of my co-workers in the research unit of my school, focuses on such hybrid practices and on how to transform art and design education from their original focus on hyper-individual work portfolio development towards studying and working in such multidisciplinary projects and contexts.

PJ: In your recent article, you draw a parallel between Luther Blissett's Q and QAnon (Cramer and Ming 2020). What is the role of the arts in relation to growing conspiracy movements, fake news and post-truth condition?

FC: The conspiracy movements re-enact and reuse practically everything from the arsenal of subversive conceptual and performance art (particularly if you think of its pre-1989 Eastern European versions), and from 'culture jamming' and 'tactical media' of the 1990s. As I learned from the musician, composer and chaos magic expert Leo Svirsky, ${ }^{10}$ this started at least with Vladislav Surkov's blend of theatre and pro-Putin propaganda in early 2000s Russia, but maybe-as a Croatian-you would know earlier examples from ex-Yugoslavia.

\footnotetext{
7 See https://mi2.hr/en/programi-i-projekti/javna-knjiznica/. Accessed 18 Febuary 2021.

8 See https://www.documenta.de/en/. Accessed 18 Febuary 2021.

9 See https://universes.art/en/documenta/2022/ruangrupa. Accessed 18 February 2021.

10 See https://leosvirsky.com/. Accessed 25 February 2021.
} 
Here in the Netherlands, a former artist who was involved in the production of the 1990 s tactical media conference, Next 5 Minutes, ${ }^{11}$ is now the chief ideologist and second-most important politician in the right-wing faction of the populist Geert Wilders. Just today, I was following social media discussions among protagonists of 1990s net.art and tactical media on the degree to which this type of art has been discredited, or at least made obsolete, by fake news culture.

If we take the Italian Luther Blissett project, ${ }^{12}$ or the Yes Men ${ }^{13}$ in the USA, then much of their work literally consisted of fake news production. Conversely, there is also the question on the degree to which contemporary trolls, memers and influencers have demonstrated a superior visual-cultural literacy to artists and designers (who are supposed to be the 'professionals' in this field), and how artists can stay with the trouble and get their hands dirty (rather than resorting to art as a safe space in a problematic sense). I have been part of a research project on 'Urgent Publishing' where we addressed exactly this question-my colleague Clara Balaguer is an expert on it-and will have a paper 'What Is Urgent Publishing?' out on this subject very soon.

PJ: The world of art is now in a paradoxical situation. On the one hand, art seems to be everywhere. On the other hand, social conditions of artists are rapidly deteriorating (especially with Covid-19), and artistic work is rapidly becoming even more elitist than in the past. How do you make sense of this dynamic?

FC: I don't have an answer. This is precisely what we are investigating and exploring in our research programme. But a possible outcome could be that the entire concept of 'art', which is specifically Western and has been, in its contemporary dictionary meaning, around for less than three centuries, will gradually lose importance or survive only in niches such as art galleries and artistic research labs. 'Culture' has been a Marxist contender to 'art' since the 1960s, 'creative industries' became a neoliberal contender in the 1990s, and others may follow, but it will likely not be Western. With the ongoing political, economic and cultural hegemony shifts from the West to East Asia, I am not a very competent person to predict what will eventually replace it.

PJ: One consequence of these developments is the increasing blurring of borders between arts and academia-and you seem to work somewhere in the middle.

FC: I am actually not an artist, and have never had an education or professional career as one. In the arts, most people consider me a theoretician and academic. So it's funny when in academia, people conversely think I'm an artist. But that brings me closer to colleagues I hold in the highest regard, such as Johanna Drucker, Douglas Kahn and Anna Poletti, who work in similar grey zones.

PJ: Can you describe these grey zones in more detail? What are the main advantages and disadvantages of working in them?

FC: Johanna, Douglas and Anna were artist book makers, sound artists, respectively zine makers, before or while they became academics. In my opinion, they are

\footnotetext{
11 See https://search.iisg.amsterdam/Record/ARCH02408. Accessed 18 February 2021.

12 See http://www.lutherblissett.net/. Accessed 18 February 2021.

13 See https://theyesmen.org/. Accessed 18 February 2021.
} 
excellent theorists, because they know their material first-hand, from their own practice, down to the gory details. They are in touch with the most recent developments in their respective fields, because they have first-hand knowledge of the artists and curiosity for their work, and because they don't care whether those artists have been institutionally or scholarly recognized.

If you are a musicologist, it is self-evident that you are able to play musical scores on the piano, and conversely if you are a musician or composer (like Kim Cascone), it is self-evident that you can write research papers on music. 'Artistic research' is really old hat in electronic music. I sometimes miss that fluency in other humanities disciplines.

PJ: In 2002, you did an interview with Cornelia Sollfrank at the annual convention of the Computer Chaos Club. You asked her, 'is hacking art and does hacking have something to do with art?' (Cramer 2002: 58) Twenty years later, how would you reply to your own question?

FC: At our art school, Willem de Kooning Academy, we have even got course modules called 'Hacking' from the second to the fourth Bachelor study year. So my answer would not only be 'yes', but that hacking has become mainstream fare in the creative industries. In our school, it is advertising students who traditionally take the hacking courses to learn about memetic campaigning and apply 'tactical media' approaches to their commercial work. All the while, 'hacking' itself has become an industry term. Just go to any 'hackathon', or to most 'hack labs' and maker spaces, which mostly lack the critical politics of the older hacker movement of, among others, Richard Stallman and the GNU project, ${ }^{14}$ the German Chaos Computer Club ${ }^{15}$ and its feminist group Häcksen to which Cornelia Sollfrank was associated.

PJ: Speaking of artistic practices, we cannot avoid the question of aesthetics. In Anti-Media: Ephemera on Speculative Arts you wrote:

I would therefore characterize post-digital aesthetics as an aesthetics in which 'digital' is (a) no longer associated with a break with previous culture although the change it brought - such as unrestrained replicability of information-is embraced, (b) seen has having no value of its own, including no particular association with technological or social progress, (c) used as a convenience but typically associated with aesthetic shortcomings, (d) avoided in the perceivable work but implicitly present as a tool of its creation or as a tacit or negative reference; or it is hybridized with pre-digital media technology. Instead of such digital or 'new media' core values as computability, reproducibility and the 'global village', post-digital aesthetics emphasizes tangibility, do-it-yourself and urban locality. Or, in semiotic terminology: digital aesthetics privileges symbols (abstract codes), post-digital aesthetics tends to privilege indexicality (traces and contextual signs). (Cramer 2013b)

Please say more about tangibility, DIY and urban locality; I'd say that all three reach beyond the traditional realm of aesthetics.

\footnotetext{
14 See https://www.gnu.org/gnu/thegnuproject.en.html. Accessed 10 February 2021.

15 See https://www.ccc.de/en/. Accessed 10 February 2021.
} 
FC: I would call them ontological, ethical and political attributes that first informed the aesthetic and which eventually amounted to one as they became integral to it. What I tried to characterize here is a phenomenon that in America is often called 'DIY spaces'. These spaces do not refer to makerspaces or fab labs, but to squat- and post-punk style community spaces that mix non-institutional art, music and community organizing, and whose typical practices include zine making, low-tech/DIY electronic music, and radio making.

If you look, for example, at zine fests and zine culture, then tangibility, DIY and locality amount to very particular and recognizable aesthetics. This is largely outside the traditional realm of aesthetics if one focuses on the idealistic tradition of aesthetic philosophy from Baumgarten and Kant to Adorno and Rancière. But if you look at philosophies of art outside that discourse, such as John Dewey's Art as Experience (1932/2005), and even to some degree Martin Heidegger's Origin of the Work of Art (1937/2008), these embodied and life-practice oriented concepts can actually be integrated into an aesthetic.

I agree that such an aesthetic still needs to be written, or explicated, rather than exist only implicitly. Hopefully, we will be able to contribute to this and other projects, in our small research unit at Willem de Kooning Academy Rotterdam, with our current project on new concepts and practices of artistic autonomy.

I wrote the text you quoted at a time when I perceived those non- or not-exclusively digital DIY arts to be much more vital and in touch with contemporary culture than, among others, the field and discourse of 'new media' and media lab art, which was ideologically invested into digitality and thus seemed, and to a large extent still seems, to be stuck in a 1990s/early 2000s time loop. I tried to make sense of these DIY practices which I eventually called 'postdigital' — such as zine making (when 1990s zine culture had largely disappeared because its makers had moved on to homepages and blogging), experimental analog film-making (at a time when it was supposed to be made obsolete by digital video), music with analog modular synthesizers (at a time when computers-laptops in particularwere supposed to replace and obsolete all previous electronic music instruments), to name only a few-because their mere existence contradicted the digital arts and new media field, which had expected the obsoletion or transformation of these practices through digital technology. I ended up disagreeing with people from my generation who had experienced the early Internet and digital technology as a liberation from traditional gatekeepers and from the material constraints of analog reproduction and dissemination, and who often ended up dismissing postdigital DIY as a nostalgic 'retro' phenomenon.

In other words, I understood the term 'postdigital' much more literally than Kim Cascone (whose main example was laptop music, as opposed to high-tech electronic studio music) (see Cascone and Jandrić 2021), but still in the same vein of an anti-laboratory aesthetic and poetics.

PJ: Your early thinking on the concept of the postdigital in works such as 'Post-Digital Writing' (Cramer 2012), 'Post-digital Aesthetics' (Cramer 2013b), 'What is "Post-digital"?' (Cramer 2015), and others, has significantly shaped art theory. Please assess the relevance of the concept of the postdigital for today's arts. 
FC: I think that, in the meantime, the term postdigital has become rather useless in the arts, because it is constantly being conflated and confused with the too-similarsounding and much better-known 'Post-Internet'. I first experienced that in 2015 when Paul Feigelfeld and I lectured at Berlin's University of the Arts as part of a public event called 'Post-digital [...] sucks [...]'. ${ }^{16}$ In the beginning, the auditorium was packed with more than one hundred people, but when we clarified that we were not speaking about Post-Internet art, more than half of them left.

Post-Internet is a tendency or style in contemporary art that peaked with the Berlin Biennial 2016. ${ }^{17}$ Its early manifestations and definitions, such as in the 2010 blog of artist and critic Gene McHugh (McHugh 2010), were actually very close to 'postdigital' in spirit. Please allow me to quote the beginning of his initial blog posting in its entirety, because I think it deserves to be better known among people studying both postdigitality and Post-Internet art:

'Post Internet' is a term I heard Marisa Olson talk about somewhere between 2007 and 2009. The Internet, of course, was not over. That's wasn't the point. Rather, let's say this: what we mean when we say 'Internet' changed and 'post Internet' served as shorthand for this change. So, what changed? What about what we mean when we say 'Internet' changed so drastically that we can speak of 'post Internet' with a straight face? On some general level, the rise of social networking and the professionalization of web design reduced the technical nature of network computing, shifting the Internet from a specialized world for nerds and the technologically-minded, to a mainstream world for nerds, the technologically-minded and grandmas and sports fans and business people and painters and everyone else. Here comes everybody. Furthermore, any hope for the Internet to make things easier, to reduce the anxiety of my existence, was simply over-it failed - and it was just another thing to deal with. What we mean when we say 'Internet' became not a thing in the world to escape into, but rather the world one sought escape from... sigh... It became the place where business was conducted, and bills were paid. It became the place where people tracked you down. ${ }^{18}$

It is ironic yet typical that the art world and art market almost completely erased this reflection and turned 'Post-Internet' into gallery art in the visual language of the Internet's popular visual culture, i.e. an Internet-age update of Pop Art. But it remains the historical achievement of Post-Internet art that it removed the divide between 'contemporary art' and 'digital art'. One needs to understand that from ca. 1990 to ca. 2010, 'contemporary art' and 'digital art'/'media art' were two separate systems with separate institutions, separate canons, separate artists and separate critics and curators. Artists who chose to go into the 'digital art'/'media art' system risked damaging their contemporary art career opportunities, because contemporary art curators used to consider digital art to be a gadget and would, in most cases, not

\footnotetext{
16 See https://youtu.be/SjJ6AQ5RUrs. Accessed 25 February 2021.

17 See http://bb9.berlinbiennale.de/. Accessed 10 February 2021.

18 See https://122909a.com.rhizome.org/. Accessed 25 February 2021.
} 
touch it with a ten foot pole. This has also to do with Western contemporary art discourse struggling with the legacy of Clement Greenberg and his demand for 'modernist' art to be 'medium-specific'. To contemporary art people, any form of 'media art' seemed like an outmoded or even reactionary Greenbergianism. Conversely, the most visible media art institutions such as $\mathrm{ZKM}^{19}$ and ars electronica ${ }^{20}$ privileged gadgety 'interactive' art and thus did their best to reinforce that prejudice.

While both 'postdigital' (a term more common for music and design) and 'PostInternet' (a term only used for fine art) overcame that systemic divide, they also became obsolete in this process. All the contemporary artistic tendencies that I closely follow-such as the Black Quantum Futurism collective ${ }^{21}$ from Philadelphia, and the Display Distribute collective ${ }^{22}$ in Hong Kong-mix art with other forms of work and knowledge, as well as online and offline activities (see Fig. 2). While it could thus be called 'postdigital' - in the sense of transcending older divides between 'contemporary art' and 'digital art' — even the attribute 'postdigital' doesn't make much sense any more since almost all art, except mainstream gallery and collector art, has become postdigital in that sense.

\section{The Crapularity Is Near}

PJ: Since 2016, you have published a series of essays on the Crapularity. The term arrived into being as a playful contrast to Ray Kurzweil's singularity (2005); in your words, the Crapularity is defined as 'as everything that is about to go wrong in the "Singularity" (Cramer 2018a). But the Crapularity is not just about contrasting it with Kurzweil's Singularity. 'The Crapularity also describes collections of gallery and museum art that pile up in the spare rooms of the art system, i.e. the museum depots whose size continually grows in relation to exhibition space, and the tax-free airport storage facilities that private collectors use today.' (Cramer 2018a). Furthermore, '[i]n a general sense, the Crapularity is a form of accumulation of capital' (Cramer 2018a). What is the Crapularity, and why did you find it important enough to dedicate few years of your life to writing about it?

FC: The term was coined by Justin Pickard in a playful and hilarious collaborative document of futurologists on 'Alternatives to the Singularity' (Raford 2011) (see Fig. 3). This paper historically coincided with the rise of 'Smart Cities', 'Big Data', the new AI boom and the invention of Bitcoin and other crypto currencies. In the humanities and the arts, it coincided with the rise of quantitative analysis in Digital Humanities and parts of software studies, and the intellectual and arts fashion of accelerationism and even transhumanism (including its later extreme-right form of 'Neoreaction'). At that time, white cube art curators suddenly became blockchain evangelists. Here in the Netherlands, the government had initiated a paradigm shift

\footnotetext{
19 See https://zkm.de/en. Accessed 10 February 2021.

20 See https://ars.electronica.art/news/en/. Accessed 10 February 2021.

21 See https://www.blackquantumfuturism.com/. Accessed 10 February 2021.

22 See https://displaydistribute.com/. Accessed 10 February 2021.
} 
from arts to creative industries and made the Dutch representative of Ray Kurzweil's Singularity University ${ }^{23}$ a member of its creative industries steering committee. It was as if early 1990s 'Mondo 2000'-style cyberculture, ${ }^{24}$ with all its hyperbole, was back with a vengeance.

What frustrated me is that most if not all of these technologies, and the whole assumption of a near 'Singularity', are based on operationally simplified concepts of meaning/semantics, of interaction and ultimately of society and culture. You would expect people from the arts and humanities to act as correctives in this discourse, since, for example, someone schooled in literary interpretation should easily be able to point out the flaws in computational 'analytics' of texts, or somebody schooled in the arts should easily be able to debunk naive AI concepts of creativity. But this rarely happened. [Johanna Drucker's (2012) paper, 'Humanistic Theory and Digital Scholarship', is one of the notable exceptions.] So, I felt the need to help debunk the hype.

PJ: A few years ago you published an article on 'Crapularity Aesthetics' (Cramer 2018a). What is the difference between the postdigital aesthetic and the Crapularity aesthetic?

FC: They are, from my perspective, exact opposites: local, embodied, material practices versus disembodied artefacts. The former include examples of Display Distribute (Fig. 2) and Black Quantum Futurism (Fig. 5). For the latter, examples, which I also gave in my essay, include AI bots, Zombie Formalist painting and blockchain art-such as the Ethereum-based 'Non-Fungible Tokens' of meme images that are now being traded as collectible autographs by the art auction house Christie's (Sansom 2021), or the zombie (possibly bot-generated) 'Peppa Pig' cartoon videos on YouTube that James Bridle analysed in his (2018) book New Dark Age: Technology and the End of the Future.

PJ: You also wrote about 'Crapularity Hermeneutics' (Cramer 2018b). What are its main challenges?

FC: Actually, the denial of hermeneutics as such-the assumption that hermeneutical competency is either expendable or that it can be fully modelled by quantitative means. In that text, I am particularly referring to algorithmic text 'analytics' and its positioning to do what hermeneutic text analysis and interpretation conventionally do, and what the limitations of automatic and quantitative analytics versus qualitative, hermeneutic text reading are.

PJ: Most of us in the academia see openness as a positive thing. Open source, open publishing... yet you draw a clear link between openness and 'the resurgence of fascism and other forms of populism in the context of the crapularity' (Cramer 2018 b). Please elaborate on this link-does that mean that openness is not all it is cracked up to be?

FC: To give some historical context, I wrote this text in the summer of 2016, shortly before Donald Trump was elected president of the United States. The

\footnotetext{
23 See https://su.org/. Accessed 23 February 2021.

24 A digital archive of Mondo 2000 magazine can be found here: https://archive.org/details/mondohistory. Accessed 23 February 2021.
} 


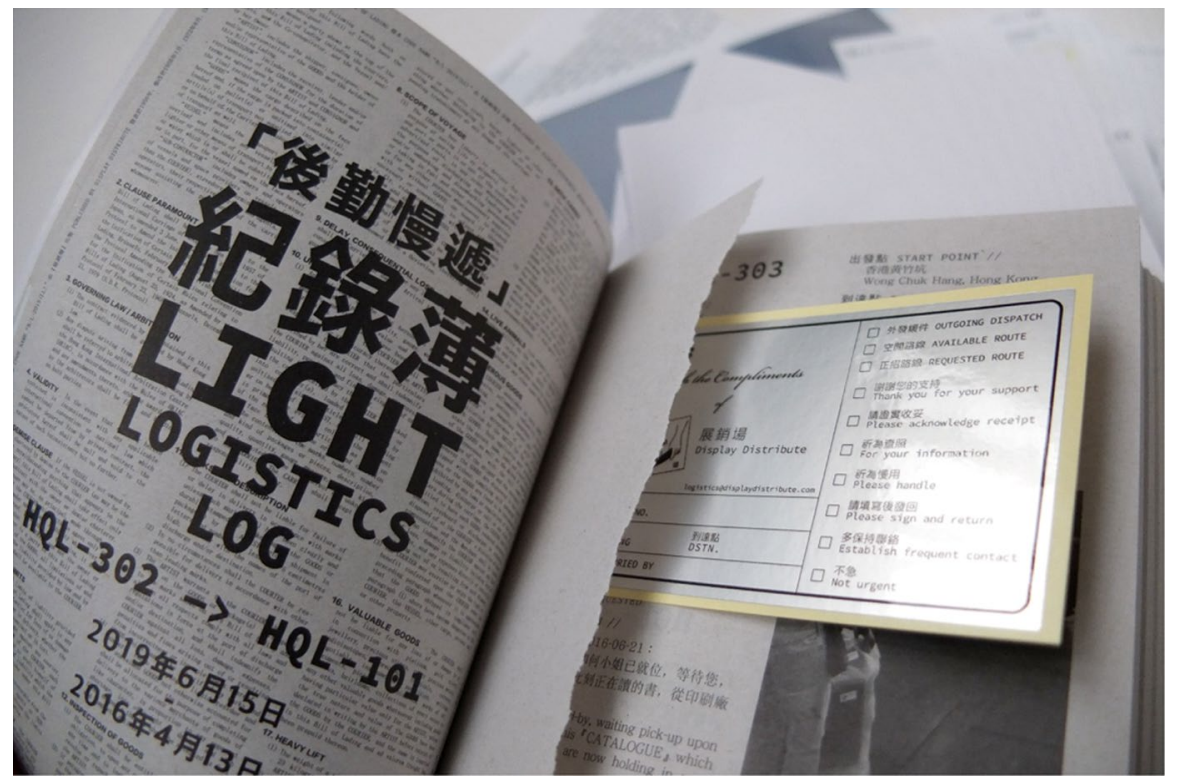

Fig. 2 Light Logistics. Documenting current courier transactions in Display Distribute's CATALOGUE No. 4. CDisplay Distribute, 2020. Reproduced with author's permission

concept of openness goes back to the liberal political philosophy of Karl Popper and his book The Open Society and its Enemies (1934/2005), and also to his earlier work on modern science as being based on falsification (instead of absolute truth claims) (Popper 1945/2020). It exists in the philosophical and ideological vicinity to Adam Smith's 'invisible hand' (1776/2007), to the concept of self-regulating open systems in early General System Theory, and has close affiliation to the Mont Pelerin Society, the main intellectual force of post-WWII neoliberalism of which Popper was a member (Mirowski and Plehwe 2009).

In essence, openness is a liberal, a neoliberal and, to some degree (i.e. for some but not all currents of libertarianism), a libertarian concept. I agree with you that it is the most attractive and, in its possible radical consequences, most interesting idea developed in that school of thought. But it also has at least two dark sides. One is what we are currently experiencing in the Covid-19 pandemic, with the virus deniers and anti-containment militancy, as reactionary openness of an aggressive ego-liberalism that demands openness literally at the price of other people's death. (I therefore wouldn't be surprised if future historians will place the hegemonial peak of the Western [neo]liberal model between 1989 and 2019, and describe its inadequacy in responding to the pandemic — and, for the same reasons, to climate change- as comparable to China's historical defeats in the Opium Wars.)

The other is the model of the open society as a superficially aimless, depoliticized, self-regulating equilibrium that amounts to post-democracy as defined by Colin Crouch (2004). This is a society in which political agency is delegitimized or outright denied through technocratic-procedural arguments (such as Thatcher's and 


\section{The Crapularity}

\author{
3D printing + spam + \\ micropayments $=$ tribbles \\ that you get billed for, as it \\ replicates wildly out of \\ control.

\section{$90 \%$ of everything is rubbish, and it's all in your spare room - or someone else's spare room, which you're forced to rent through AirBnB.}

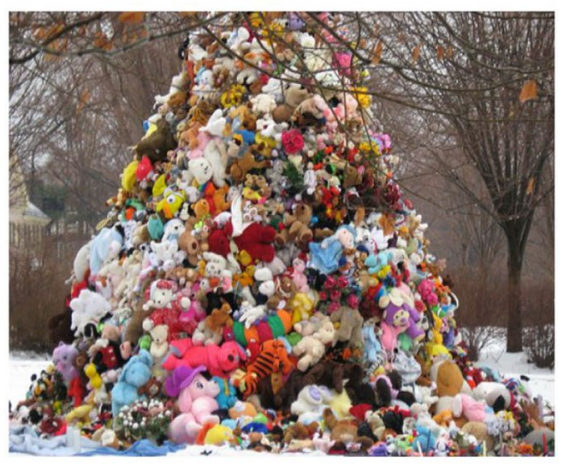

A pile of worthless "crapjects" (neologism coined by @iftf)

\section{Source: @justinpickard}

Fig. 3 The original definition of the Crapularity (Raford 2011)

Merkel's 'there is no alternative'). In the text you quoted, I interpreted the rise of populism, in its quite diverse ideological forms, and the rise of fascism, as claiming agency against equilibrium post-politics.

PJ: In 'Welcome to the Crapularity: Design as a Problem' (Cramer 2019) you wrote: 'Ever since design ceased to restrict itself to products and services, it has taken up ambitions of reinventing the world that, in the past, had been the domain of radical art and political movements.' I read this critique as being primarily about the Silicon Valley model of design as a motor of social change-for instance, by designing apps that connect service providers and customers in new ways, apps like Uber and Airbnb have transformed political economies of whole sectors such as transportation and accommodation. It is easy to claim that, in the process, design has become 'a problem rather than a solution' (Cramer 2019). Please describe this problem in more detail. What is its possible solution?

FC: Actually, my text was not about Silicon Valley at all, and your question tells me that I am falsely taking things for granted because I work at a design school. If you look at design, how it is being taught and discussed today, then you see that it has much higher ambitions and is much less artisanal than in the past. (Notable exceptions in that past would be Buckminster Fuller and Victor Papanek.) The keywords here are: social design, service design, design thinking, sustainability design. At our school, we even have a Bachelor program called Lifestyle Transformation 
Design. ${ }^{25}$ Perhaps confusingly, these design disciplines often no longer design tangible products, but social processes.

So, what I observed, or rather stated as the obvious, was a reversal of roles. Most contemporary artists dropped the idea of reinventing society through radical experiments after the 1970s. That idea got taken up by design, but in less radical ways. This created the issue of design having become messianic, as it is still based on the idea and work process of designers being confronted with a problem and designing a solution. With the extension of design from objects to social processes, every social problem thus potentially becomes a design challenge. There is a general lack of awareness - to quote my research centre colleague, Renee Turner, from a conversation-'not to turn other people's misery into our design problem'.

In the above text, I suggest that well-intentioned design projects can do more harm than good and eventually become the problem themselves. A classic example would be a social design project for an impoverished neighbourhood that ends up gentrifying it and driving out the very people it was supposed to serve. A way out of this dilemma would be, in my opinion, to stop thinking of design as problem solving.

\section{Postdigital: a Term That Sucks but Is Useful}

PJ: The concept of the postdigital may have become less useful for the arts, yet the journal Postdigital Science and Education and its book series have moved the concept towards the humanities and social sciences, where we still find it very productive. Please describe your personal road to postdigital thinking; how did your understanding of the concept change over time?

FC: Most credits go to Tara Transitory, who studied with us at Piet Zwart Institute from 2007 to 2009 and, as an electronic musician, introduced me to the term and to Kim Cascone's (2000) essay 'The aesthetics of failure: "Post-digital" tendencies in contemporary computer music'. She graduated, in a digital media design program, with a reel-to-reel tape loop installation while also experimenting, as early as in 2008, with buffer breakdowns from streaming live music performances. In her practice, she has deepened postdigitality towards a post- and decolonial poetics, and recently returned to tape loop installations with her partner Nguyễn Baly at daadgalerie in Berlin (Fig. 4). One can, by the way, revisit that installation as a virtual reality piece, with the tape loop running as a 3D simulation. ${ }^{26}$

Alessandro Ludovico, who wrote the book Post-Digital Print: The Mutation of Publishing since 1894 (2012) as a fellow in our research program, prompted me to further explicate the term since his book uses it in a rather implicit manner. More

\footnotetext{
25 See https://www.rotterdamuas.com/programmes/bachelor/lifestyle-transformation-design/. Accessed 24 February 2021.

${ }^{26}$ See https://hub.greenhousenaxos.com/ofW9Asy/nguyen-transitory-topography-of-vulnerabilities-3/ (works only in Mozilla Firefox). Accessed 25 February 2021.
} 
credits go to the artist-run spaces WORM ${ }^{27}$ (with its artist-run film lab and modular synthesizer studio), De Player ${ }^{28}$ and Extrapool ${ }^{29}$ (with its Riso printing workspace) in the Netherlands, along with the projects of many students at Piet Zwart Institute (including among others Linda Hilfling, Ivan Monroy Lopez, Stéphanie Vilayphiou, Dennis de Bel, Albert Jongstra, Darija Medić, Lieven van Speybroeck, Amy Suo Wu and Nan Wang), plus artists such as Goodiepal and Black Quantum Futurism whose practices transcended the artificial divides between 'analog' and 'digital', 'old' and 'new' media.

In the period between 2006 and 2010, when I worked as a course director of a media design program, I simply saw that terms such as 'new media art', 'net art' and 'software art' were over-specific and failing younger generations of artists. The net.art generation of the 1990s did, and often still does, understand the Internet and digital file sharing as a commons that liberates culture from traditional institutions and 'ancien régimes' of authorship and ownership. But for many of our students, this no longer reflected their reality. They lived and worked in a time of upcoming social media and Internet platform capitalism and their new regimes. So it was only logical for them to imagine and practically experiment with alternative systems and regimes that were no longer aligned to the analog/digital divide. This is what the term 'postdigital' was capturing for me, and so I found it a good idea to take it up from Kim Cascone and help update it for the 2010s.

PJ: I've got this presentation, 'creatively' entitled 'Postdigital Science and Education', which serves to introduce the concept of the postdigital and the Postdigital Science and Education publishing ecosystem to new audiences. As you can imagine, I've given this presentation more time than I care to think of... In one slide, speaking of problems associated with the term 'postdigital' I just show your 'definition' from 'What is "Post-digital”?' (Cramer 2015): 'a term that sucks but is useful'. Every time I show this slide, from Europe, America, and Australia to China and Russia, I inevitably hear audiences chuckle...

While we try to avoid too much navel-gazing, the Postdigital Science and Education community has extensively debated the concept of the postdigital; reasons why it sucks, and why/how it can be useful. What, in your opinion, are the main problems and potential contributions of the concept in the year 2021 ?

FC: The term sucks and is counter-intuitive, because we are not living in postdigital times in any literal sense. When, for example, more and more aspects of daily life depend on Internet platforms during the pandemic-from food delivery to teleconferencing-or when economic analysts describe Tesla's competitive advantage that its cars have been constructed as a central piece of software with an attached engine, as opposed to traditional cars which have software as an add-on to their components; when, in other words, almost every aspect of life becomes more, not less digital, then the term 'postdigital' doesn't seem to make sense. But when that

27 See https://worm.org/. Accessed 10 February 2021.

28 See https://www.deplayer.nl/. Accessed 10 February 2021.

29 See https://extrapool.nl/. Accessed 10 February 2021. 


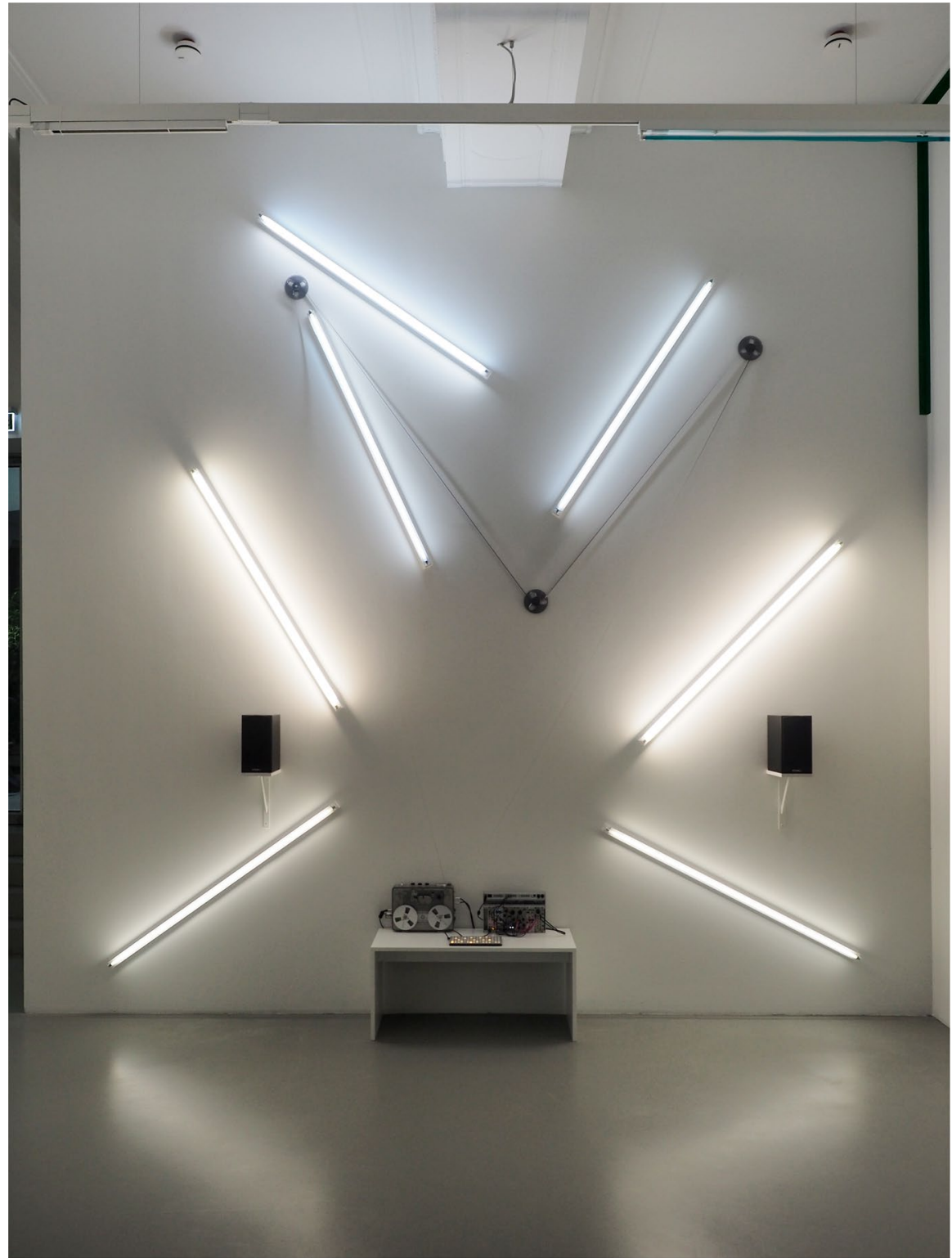

Fig. 4 Nguyễn [Baly] and [Tara] Transitory, Topography of Vulnerabilities \#1. Analog/digital sound installation at daadgalerie, Berlin 2020. Photograph: Udo Siegfriedt. (C) Udo Siegfriedt, reproduced with author's permission

happens, 'digital' ceases to describe a difference and simply becomes the default state or condition.

To pick a simple example: Almost nobody would still call a digital camera 'digital camera'; people simply refer to it as a camera. This was different when I wrote 
my essay 'What is "Postdigital"?' (Cramer 2015); at that time, my school still had a Bachelor program called 'Digital Photography'. Even fewer people would call a digital audio recorder a digital audio recorder because they might not even know that reel-to-reel audio recorders existed. On the contrary, most people would likely find the use of a film camera or a reel-to-reel audio recorder more remarkable and end up calling it an 'analog camera', respectively an 'analog recorder'. Factually, even these devices have become postdigital through most users digitizing their film pictures and tape recordings at some point in post-production-aside from the fact that an 'analog' 35-mm film camera is actually a hybrid digital-analog system, since its (countable, discrete) frames technically constitute a digital system.

The best possible contribution of the concept 'postdigital' in 2021 is, in my opinion, that it can help to complicate the terms 'digital' and 'analog', particularly in the humanities and social sciences. It could also be used for fields of technology that are literally postdigital, such as biocomputing and continuous variable quantum computing.

PJ: I would argue that there are other important contributions as well! For instance, postdigital theory has always had a strong interest in publishing (e.g. Ludovico 2012). In a recent paper, 'Hybrid Publishing: Between Print and Electronics, Art and Research', you argue that '[f]or new forms of interdisciplinary and artistic research, there is a corresponding need for new forms of publishing that go beyond the traditional academic textbook' (Cramer 2018c). Obviously, modes of publishing are closely related to modes of knowledge production... Which new forms of knowledge are now emerging in our postdigital condition? What is their relationship between (artistic and non-artistic) modes of publishing and dissemination?

FC: Probably the best-known contemporary example is the Forensic Architecture research collective, ${ }^{30}$ which uses digital design tools in audiovisual media as both as research tools and forms of dissemination. Another one is the Feral Atlas, ${ }^{31}$ an exploration of 'ecologies that have been encouraged by human-built infrastructures, but which have developed and spread beyond human control'. It is being developed as a simultaneous research and online publication platform by a multidisciplinary collective that involves anthropologist, Anna Lowenhaupt Tsing, visual culture researcher, Jennifer Deger, environmental anthropologist, Alder Keleman Saxena, and graphic designer, Feifei Zhou.

Outside academic institutions, I could mention again the work of artist-research collectives such as Display Distribute from Hong Kong, which, among others, runs an international courier service 'Light Logistics' as a research project. This courier service reflects on the economic and political cross-border relations between Hong Kong and Mainland China where goods are being semi-officially transported across the borders, and the precarious state of independent publishing in Hong Kong. 'Light Logistics' is run by volunteer collaborators and is based on personal travels

\footnotetext{
30 See https://forensic-architecture.org/. Accessed 18 February 2021.

31 See https://feralatlas.org. Accessed 18 February 2021.
} 
and encounters, but also involves a complex online and offline tracking bureaucracy (see Fig. 2).

There is the Black Quantum Futurism from Philadelphia, which, among others, explores alternative concepts of time and mixes sciences, politics and speculative thinking and speculative technologies in workshops, concerts, performances, zines, exhibitions and books, often also in formats that combine fiction readings with experimental electronic music (see Fig. 5). I'd also like to mention the Jatiwangi art Factory from Indonesia ${ }^{32}$ which conducts material artistic research, residencies and community projects that explore 'Tanah' (clay, soil, earth) as a local resource.

Much of this has been traditionally framed as 'artistic research' because it manifests itself in formats that are traditionally associated with contemporary art, but I would argue that these practices manifest new types of research, gathering and dissemination of knowledge beyond their significance as contemporary artistic practices. By the way, in all these examples, digital and non-digital practices and media are being mixed and interconnected.

PJ: Technologies are constitutive parts of capitalism. Based on their focus, recent authors have described various transformations of capitalism using concepts such as data capitalism (Fuchs 2019), algorithmic capitalism (Peters and Jandrić 2018: 32), communicative capitalism (Dean 2009; Ford 2018), surveillance capitalism (Zuboff 2019), technoscientific capitalism (Birch and Muniesa 2020) and high-tech and lowpay capitalism (Marcy 2009). Coming 'after mercantile, industrial, and knowledge capitalisms' (Peters 2012: 105), bioinformational capitalism is 'based on a selforganizing and self-replicating code that harnesses both the results of the information and new biology revolutions and brings them together in a powerful alliance' (Peters 2012: 105).

Today, one of the best examples of bioinformational capitalism is the interplay between national politics, international politics and global pharmaceutical corporate sector, in various struggles over Covid-19 vaccines. Bioinformational capitalism, and our Covid-19 reality, also causes significant reconfigurations in the world of arts (Kuzmanić and Jandrić 2020). What are the main challenges facing arts in this context?

FC: Frankly, I wonder whether the entire system of the arts-which is pretty much a Western invention of the last three centuries-inasmuch as it is centred on public (or semi-public) venues, will be able to survive. I would not be surprised if it collapsed or at least radically transformed itself. And even if you just remove small pieces from the puzzle, such as the ceaseless international (air) travel of artists and curators, it will be radically reconfigured, and will likely end up in a major legitimacy crisis. I can tell from some first-hand insight into cultural institutions that a real fear of their directors and curators is that the pandemic will make people realize that for all their cultural needs, a Netflix subscription is enough and the rest is expendable.

PJ: Back to your definition of postdigital aesthetics (Cramer 2013b), I'd also argue that DIY also has a big role in these recent transformations of the arts system...

$\overline{32}$ See https://jatiwangiartfactory.tumblr.com. Accessed 18 February 2021. 


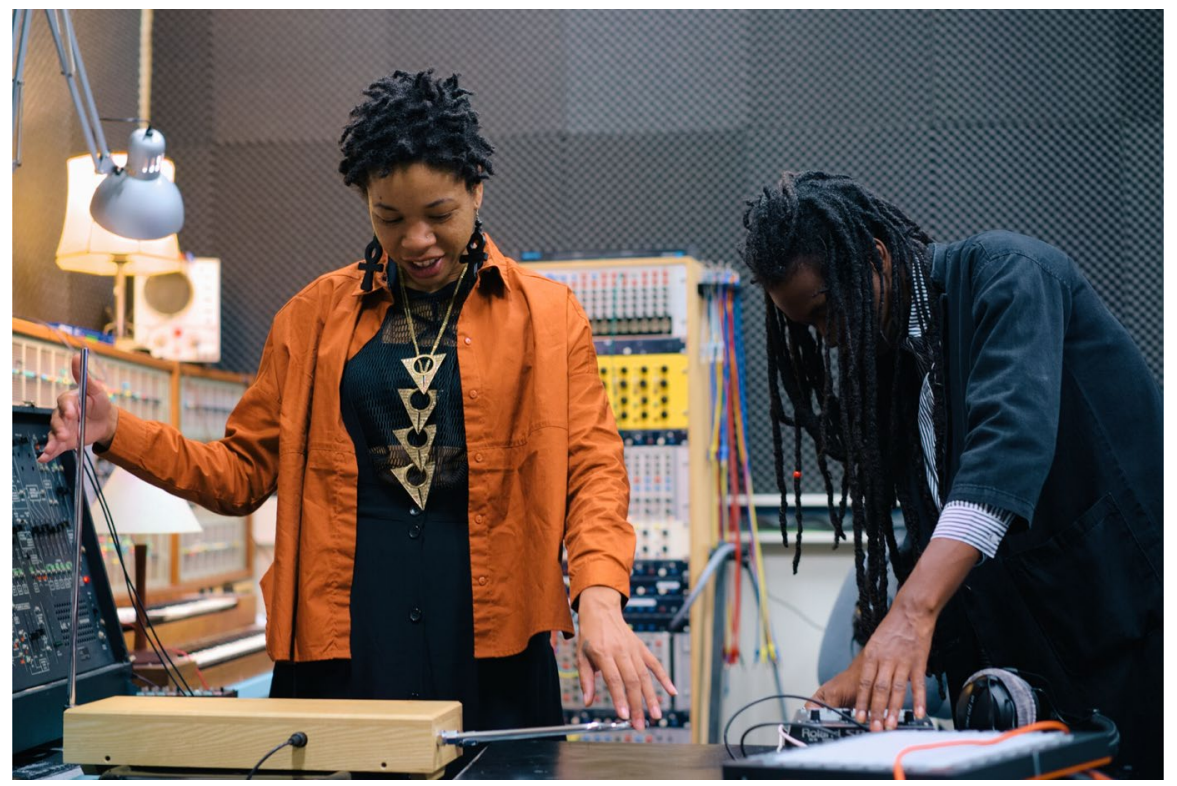

Fig. 5 Black Quantum Futurism (Rasheedah Phillips and Camae Ayewa/Moor Mother) recording with hybrid analog and digital electronic instruments in WORM's synthesizer studio, Rotterdam, August 2016. Photograph: Florian Cramer. Creative Commons Attribution-ShareAlike 4.0 International license (CC BY-SA 4.0)

FC:Yes, in the way its institutions have to improvise and reinvent their activities. But when this just boils down to streaming events via teleconferencing (which is hardly bearable for people who spent whole workdays in front of their webcam), or having a person or a robot walk through an exhibition with a camera for remote viewers-I am not very optimistic about this type of DIY.

Here in Rotterdam, the place that was the main source for my writing on postdigitality, WORM transformed into a community radio station during the pandemic, which works amazingly well, and brings back joy and purpose to the arts. (I might be a bit biased because I have my own program on that radio.) I attribute that to an undogmatic, DIY, postdigital mentality of not being overly attached, or invested into, one particular medium - no matter whether that medium is a white cube or the Internet.

PJ: Your recent article, 'Letters from dystopian and utopian futures of arts education' (Cramer and Teran 2020), is a piece of speculative fiction aimed at making sense of our present. Yet I cannot help but ask you to play a bit further: What, in your opinion, is the future of arts and arts education after Covid-19?

FC: This is an open question, and thus a genuine research question-and what Michelle Teran, I and my colleagues at Willem de Kooning Academy and the other research projects that mentioned, are investigating. It would be presumptuous if we claimed to know the future of arts and art education, but the examples of current 'blurry' practices I gave before might indicate a larger tendency and development. 
Acknowledgements We extend our deepest thanks to Alison MacKenzie for her valuable comments and suggestions on this article.

\section{References}

Birch, K., \& Muniesa, F. (Eds.). (2020). Assetization: turning things into assets in technoscientific capitalism. Cambridge, MA: MIT Press.

Bridle, J. (2018). New Dark Age: Technology and the End of the Future. London: Verso.

Cascone, K. (2000). The aesthetics of failure: 'Post-digital' tendencies in contemporary computer music. Computer Music Journal, 24(4), 12-18.

Cascone, K., \& Jandrić, P. (2021). The Failure of Failure: Postdigital Aesthetics Against TechnoMystification. Postdigital Science and Education. https://doi.org/10.1007/s42438-020-00209-1.

Cramer, F. (2002). Hacking the Art OS--Interview with Cornelia Sollfrank. Rhizome, 31 March. https:// rhizome.org/editorial/2011/apr/28/rhizome-archives-hacking-art-os-interview-cornelia/. Accessed 22 March 2021.

Cramer, F. (2005). Words Made Flesh: Code, Culture, Imagination. Rotterdam: Piet Zwart Institute.

Cramer, F. (2011). Exe.cut[up]able statements: Poetische Kalküle und Phantasmen des selbstausführenden Texts. Paderborn, Germany: Wilhelm Fink.

Cramer,F.(2012).Post-DigitalWriting.ElectronicBookReview,12December.http://electronicbookreview.com/ essay/post-digital-writing/. Accessed 2 February 2021.

Cramer, F. (2013a). Anti-Media: Ephemera on Speculative Arts. Rotterdam and New York: NaiOlO Publishers and Institute of Network Cultures.

Cramer, F. (2018a). Crapularity Aesthetics. Making and Breaking, 1. https://makingandbreaking.org/ article/crapularity-aesthetics/. Accessed 2 February 2021.

Cramer, F. (2018b). Crapularity Hermeneutics. In W. H. K. Chun, H. Steyerl, C. Apprich, \& F. Cramer, Pattern Discrimination (pp. 23-58). Minneapolis, MN: University of Minnesota Press.

Cramer, F. (2018c). Hybrid Publishing: Between Print and Electronics, Art and Research. https:// publications.rasl.nu/read/reflective/hybrid-publishing-between-print-and-electronics-art-andresearch?search=Hybrid+Publishing. Accessed 11 February 2021.

Cramer, F. (2019). Welcome to the Crapularity: Design as a Problem. Archined, 16 November. https://www.archined.nl/2019/11/welcome-to-the-crapularity-design-as-a-problem/. Accessed 2 February 2021.

Cramer, F. (2020). A Poetics of Exhaustion: Looking at the Automation of Literature from its Dead Ends. https:// studip.tu-braunschweig.de/plugins.php/coreforum/index/index/2f9a12c0de6bd98fbe932a138c4e50b2? cid=6a4c969e34c005476f21a8fa4800ded4. Accessed 18 February 2021.

Cramer, F., \& Ming 1, W. (2020). Blank Space QAnon. On the Success of a Conspiracy Fantasy as a Collective Text Interpretation Game. https://www.wumingfoundation.com/giap/blank-space-qanon/. Accessed 11 February 2021.

Cramer, F., \& Teran, M. (2020). Letters from dystopian and utopian futures of arts education. In D. P. Gijsbertse, H. A. Van Klink, C. Machielse, \& J. H. Timmermans (Eds.), Hoger beroepsonderwijs in 2030: Toekomstverkenningen en scenario's vanuit Hogeschool Rotterdam (pp. 427-464). Rotterdam: Hogeschool Rotterdam Uitgeverij.

Cramer, F. (2013b). Post-digital aesthetics. Lemagazine, 1 May. http://lemagazine.jeudepaume.org/2013/05/ florian-cramer-post-digital-aesthetics/. Accessed 4 February 2021.

Cramer, F. (2015). What is 'post-digital'? In D. M. Berry \& M. Dieter (Eds.), Postdigital aesthetics: Art, computation and design (pp. 12-26). New York: Palgrave Macmillan. https://doi.org/10.1057/9781137437204_2.

Crouch, C. (2004). Post-Democracy. Cambridge, UK and Malden, MA: Polity.

Dean, J. (2009). Democracy and other neoliberal fantasies: communicative capitalism and left politics.Durham and London: Duke University Press.

Dewey, J. (1932/2005). Art as Experience. London: Penguin.

Drucker, J. (2012). Humanistic theory and digital scholarship. Debates in the Digital Humanities, 150, 85-95. https:// dhdebates.gc.cuny.edu/read/untitled-88c11800-9446-469b-a3be-3fdb36bfbd1e/section/0b495250-97af4046-91ff-98b6ea9f83c0\#ch06. Accessed 23 February 2021. 
Ford, D. R. (2018). Queer communist study: the sinthomostudier against the capital-debt-learning regime. Journal of Curriculum and Pedagogy, 15(1), 8-23. https://doi.org/10.1177/ 0725513612444562.

Fuchs, C. (2019). Karl Marx in the age of big data capitalism. In D. Chandler \& C. Fuchs (Eds.), Digital Objects, Digital Subjects: Interdisciplinary Perspectives on Capitalism, Labour and Politics in the Age of Big Data (pp. 53-71). London: University of Westminster Press. https://doi.org/10.16997/ book29.d.

Fuller, M. (Ed.). (2008). Software Studies: A Lexicon. Cambridge, MA: MIT Press.

Heidegger, M. (1937/2008). On the Origin of the Work of Art. In D. F. Krell (Ed.), Martin Heidegger: Basic Writings (pp. 143-212). New York: HarperCollins.

Jones, C. (2018). Experience and networked learning. In N. Bonderup Dohn, S. Cranmer, J. A. Sime, M. de Laat, \& T. Ryberg (Eds.), Networked learning: Reflections and challenges (pp. 39-56). Springer International. https://doi.org/10.1007/978-3-319-74857-3_3.

Kittler, F. (1992). There Is No Software. Stanford Literature Review, 9, 81-90.

Kurzweil, R. (2005). The Singularity Is Near: when humans transcend biology. New York: Viking.

Kuzmanić, A., \& Jandrić, P. (2020). Art Without Place. Zagreb: Oaza.

Lachmann, R. (2002). Erzählte Phantastik. Frankfurt: Suhrkamp.

Lessig, L. (1999/2006). Code and Other Laws of Cyberspace. New York: Basic Books.

Ludovico, A. (2012). Post-Digital Print: The Mutation of Publishing since 1894. Eindhoven: Onomatopee.

Manovich, L. (2002). The Language of New Media. Cambridge, MA: MIT Press.

Marcy, S. (2009). High tech, low pay: a Marxist analysis of the changing character of the working class. New York: World View Forum.

Mattenklott, G. (1989). Ästhetische Anthropologie in Goethes zweitem "Faust." In G. Gebauer, D. Kamper, C. Wulf, K. Wünsche, D. Lenzen, \& G. Mattenklott (Eds.), Historische Anthropologie (pp. 217-252). Hamburg: Rowohlt.

McHugh, G. (2010). Post Internet. https://122909a.com.rhizome.org/. Accessed 25 February 2021

McLaren, P. (2020). Networked Religion: Metaphysical Redemption or Eternal Regret? Postdigital Science and Education. https://doi.org/10.1007/s42438-020-00112-9.

Merrison, L. (2001). Friends in High Places [Documentary Film]. Zürich: Dschoint Ventschr Filmproduktion.

Mirowski, P., \& Plehwe, D. (Eds.). (2009). The Road from Mont Pelerin: The Making of the Neoliberal Thought Collective. Cambridge, MA: Harvard University Press.

Moioli, C. (2016). Neoism now \& then. In conversation with Florian Cramer. Brescia: Link Editions.

Oppitz, M. (1981). Shamans of the Blind Country [Documentary Film]. New York and Cologne: WSKProductions Inc. and Westdeutscher Rundfunk (WDR)

Osborne, P. (2013). Anywhere or Not at All: Philosophy of Contemporary Art. London: Verso.

Peters, M. A. (2012). Bio-informational capitalism. Thesis Eleven, 110(1), 98-111. https://doi.org/10. $1177 / 0725513612444562$.

Peters, M. A., \& Jandrić, P. (2018). The digital university: a dialogue and manifesto. New York: Peter Lang.

Popper, K. R. (1934/2005). The Logic of Scientific Discovery. New York: Routledge.

Popper, K. R. (1945/2020). The open society and its enemies. Princeton, NJ: Princeton University Press.

Raford, N. (2011). Alternatives to the Singularity. https://monoskop.org/images/0/03/Alternatives_to_ the_Singularity_2011.pdf. Accessed 23 February 2021.

Sansom, A. (2021). Christie's to accept cryptocurrency for first time. The Art Newspaper, 19 February. https://www.theartnewspaper.com/news/christie-s-cryptocurrency. Accessed 1 March 2021.

Smith, A. (1776/2007). An Inquiry into the Nature and Causes of the Wealth of Nations. Metalibri.

Sollfrank, C. (2004). (Ed.). Net.Art Generator. Nuremberg: Verlag für moderne Kunst.

Stockhammer, R. (2000). Zaubertexte: Die Wiederkehr der Magie und die Literatur 1880-1945. Berlin: Akademie Verlag.

Wiener, N. (1950). The Human Use of Human Beings. Boston, MA: Houghton Mifflin Harcourt.

Zuboff, S. (2019). The age of surveillance capitalism: the fight for a human future at the new frontier of power. New York: PublicAffairs. 